\title{
Human Glandular Kallikrein
}

National Cancer Institute

\section{Source}

National Cancer Institute. Human Glandular Kallikrein. NCI Thesaurus. Code C20343.

The glandular kallikrein gene family comprises 25-30 homologous genes that encode specific proteases involved in the processing of biologically active peptides. Expression of glandular kallikrein, like PSA, seems to be restricted to the prostate. (from OMIM 147960 and $\mathrm{NCl}$ ) 